\title{
Antioxidant activity and acute toxicity of two Lagenaria siceraria (Molina) Standl. varieties from Sudan
}

\author{
Abdalbasit Adam MARIOD 1,2,3, Makarim Mutasim Mohamed MUSTAFA ${ }^{4}$, Abdelazim Ahmed Mohamed \\ NOUR $^{5}$, Mahmood Ameen ABDALLA ${ }^{6}$, Suzy Munir SALAMA ${ }^{7}$, Nahla Saeed Al WAJEEH ${ }^{7}$
}

Received January 22, 2019; accepted October26,2020.

Delo je prispelo 22. januarja 2019, sprejeto 26. oktobra 2020.

\begin{abstract}
Antioxidant activity and acute toxicity of two Lagenaria siceraria (Molina) Standl. varieties from Sudan

Abstract: The present study was conducted to evaluate the antioxidant capacity and acute toxicity of the methanol extract of two Lagenaria siceraria (Molina) Standl. varieties of dried seeds, Sweet gourd Water Jug (WJ) and bitter gourd Basket Ball (BB). The seed extracts were tested for their total phenolic contents (TPC), total flavonoid contents (TFC), ferric reducing antioxidant power (FRAP) and scavenging activity to the stable free radical 2,2-diphenyl-1-picrylhydrazyl (DPPH). Both dried seed extracts were then tested for acute toxicity at doses 2 and $5 \mathrm{~g} \mathrm{~kg}^{-1}$ each. Sixty female and male rats were assigned into five groups per sex. Four groups were given low and high doses of each dried seed extract and the fifth group was given $10 \%$ Tween 20 as a control. Kidneys and livers of all rats were assessed for biochemistry and histopathology. The seed extract of WJ revealed higher TPC, FRAP and DPPH activities compared to BB seeds, while TFC results were reversed. Toxicologically, no toxicity signs were recorded in animals. Biochemistry results were within the normal ranges with a slight increase in bilirubin and Alanine aminotransferase (ALT), and histology of kidneys and livers showed normal architecture. In conclusion, WJ and BB dried seed extracts exhibited high antioxidant activity suggesting promising therapeutic regimen against oxidative stress.
\end{abstract}

Key words: Lagenaria siceraria; antioxidant; acute toxicity
Antioksidacijska aktivnost in akutna toksičnost dveh sort vodnjače (Lagenaria siceraria (Molina) Standl.) iz Sudana

Izvleček: Raziskava je bila izvedena za ovrednotenje antioksidacijske sposobnosti in akutne toksičnosti metanolnih izvlečkov suhih semen dveh sort vodnjače (Lagenaria siceraria (Molina) Standl.)), sladke 'Water Jug' (WJ) in grenke vodnjače 'Basket Ball' (BB). V izvlečkih semen so bili analizirani celokupna vsebnost fenolov (TPC), celukupna vsebnost flavonoidov (TFC), velikost redukcije železa (FRAP) in lovilna aktivnost stabilnega prostega radikala 2,2-difenil-1-pikrilhidrazila (DPPH). Oba izvlečka sta bila potem preiskušena na akutno toksičnost $\mathrm{z}$ odmerkoma 2 in $5 \mathrm{~g} \mathrm{~kg}^{-1}$. 60 podganjih samic in samcev je bilo razdeljeno glede na spol v pet skupin. Vsaka od štirih skupin je dobivala velike in majhne odmerke izvlečka semen, peta skupina pa je dobila $10 \%$ Tween 20 kot kontrolo. Ledvice in jetra vseh podgan so bile ocenjene po biokemičnih in histopatoloških parametrih. Izvleček semen WJ je pokazal večjo aktivnost TPC, FRAP in DPPH v primerjavi s semeni BB, a rezultati TFC so bili obratni. Na živalih ni bilo opaziti nobenih znakov zastrupitve. Biokemični parametri so bili znotraj normalih meja $\mathrm{z}$ rahlim povečanjem vsebnosti bilirubina in aktivnosti alanin aminotransferaze (ALT). Tudi histološki pregled ledvic in jeter je pokazal normalno zgradbo. Zaključimo lahko, da imajo izvlečki suhih semen $\mathrm{WJ}$ in BB veliko antioksidacijsko aktivnost, kar obeta njihovo uporabo pri blaženju oksidacijskega stresa.

Ključne besede: Lagenaria siceraria; antioksidant; akutna toksičnost

\footnotetext{
1 University of Jeddah, College of Science and Arts, Department of Biology, Alkamil, KSA

2 Ghibaish College of Science \& Technology, Indeginous Knowledge and Heritage Centre, Ghibaish, Sudan

3 Corresponding author, e-mail: basitmariod58@gmail.com, aalnadif@uj.edu.sa

4 University of Bahri, Department of Food Science, Khartoum North, Sudan

5 University, Khartoum, Faculty of Agriculture, Department of Food Science \& Technology, Sudan

6 University of Malaya, Faculty of Medicine, Department of Molecular Medicine, Kuala Lumpur, Malaysia

7 University Malaya, Faculty of Medicine, Department of Biomedical Science, Kuala Lumpur, Malaysia
} 


\section{INTRODUCTION}

Medicinal plants are still considered as cheap and safe, natural resource of drugs with less toxicity all over the world. Sudanese locals and people of other developing countries have relied on traditional herbs to treat their diseases (Elhadi et al., 2013). Therefore, it is useful to explore more about medicinal plants (Koko et al., 2008). Family Cucurbitaceae is a very large family composed of 118 genera and 825 species. One of the most important genera of this family is Lagenaria (Molina) which is also known as bottle gourd, calabash gourd or white flowered gourd plant (Fader et al., 2013). In addition to Lagenaria siceraria, genus Lagenaria consists of five other wild species, namely $L$. brevifilora (Benth) Roberty, L. rufa (Gilg) C Jeffrey, L sphaerica E Mey, L. abyssinia (Hook. F.) C Jeffrey and L. guineensis (G Den) C Jeffrey. $L$. siceraria is an indigenous species native to India (Shah et al., 2010) and became widely spread in Africa and the most cultivable species in Asia and America (Erickson et al., 2005). Shah et al. (2010) reported that Lagenaria has two distinguished varieties, one is bitter bottle gourd and sweet variety useful bottle gourd. The bitter variety is wild plant and used for the pharmacological application, while sweet variety is used as a vegetable and medicinal. In Sudan, varieties of $L$. siceraria, the sorcerer is broadly diffused in different areas of the South and West, while some of them are edible such as snake gourd. Recently, researchers focused their study on L. siceraria varieties exploring more about their chemical composition. Studies reported that they can be used as nutritious source, in cosmetics and medicine (Mariod et al., 2015). Literature review reveals that $L . s i$ ceraria showed a broad spectrum of pharmacological activities such as antioxidant (Mayakrishnan et al., 2013), antimutagenic (Thakkar, 2013), antiulcer (Srivastava et al., 2011), anti-inflammatory (Ghule et al., 2006), antidiabetic, hepatoprotective (Deshpande et al., 2008) and cardioprotective (Upaganlawar and Balaraman, 2011). Due to the presence of high percentage of alkaloids, phenolic glycosides, carbohydrates, proteins and minerals, L. siceraria can be suggested to replace allopathic medicines (Mariod et al., 2015; Sivannarayana et al., 2013). In folk medicine, different parts (leaves, stem, flower, root, and seeds, fresh and dry fruits) of L. siceraria have been used in the ointment for ailment of various diseases $(\mathrm{Ku}-$ mar et al., 2015).

Traditionally, L. siceraria seeds can be cooked, dried and served as snacks in some countries such as Egypt. Also can be ground and fermented for use as a flavor enhancer in gravies and soups in West Africa (AchiganDako et al., 2008). At the phytochemistry level, studies proved the presence of various phytochemicals like cardiac glycosides, terpenoides, carbohydrates, resins, saponins and phytosterols in L. siceraria seeds (Sood et al., 2012). Singh et al. (2012) suggested that the ethanol extract of $L$. siceraria seeds exhibits cardioprotective potential in experimental animals against cardiac toxicity induced by doxorubicin. Another study revealed that the ethanol extract of $L$. siceraria seeds showed excellent free radical scavenging activity (Gill et al., 2012). As an extension to our previous study on the eight Sudanese Lagenaria varieties (Mariod et al., 2015), the present study was conducted to determine the total phenol and total flavonoid contents, and acute oral toxicity of the methanol extract of sweet and bitter varieties of $L$. siceraria seeds from Sudan.

\section{MATERIAL AND METHODS}

\subsection{IN VITRO ANTIOXIDANT CAPACITY STUDY OF WJ AND BB METHANOL EXTRACTS OF DRIED SEEDS}

\subsubsection{Plant material}

Two varieties of Lagenaria siceraria dry fruits \{Sweet gourd 'Water Jug' (WJ) and bitter gourd 'Basket Ball' (BB)\} were obtained from the market of Omdurman, State of Khartoum, Sudan.

\subsubsection{Preparation of seeds extracts}

By the aid of $4.8 \mathrm{~mm}$ knife, the seeds were removed from the collected dried fruits. The removed seeds were properly washed and left dried at $50{ }^{\circ} \mathrm{C}$ in drying oven (FD 115; Fisher Scientific, Loughborough, Leicestershire, UK). The dried seeds were then ground to a powder using home blender and stored in polyethylene bags in the refrigerator at $4{ }^{\circ} \mathrm{C}$ till the onset of the experiment as previously done (Mariod et al., 2015). For seed extraction, the seed powder was firstly defatted using $n$-hexane at $50-60{ }^{\circ} \mathrm{C}$ in a Soxhlet apparatus for six hours following the AOCS method (Firestone, 2009). The dried seeds (seedcake) were extracted for $72 \mathrm{~h}$ in methanol $95 \%$ at room temperature with occasional stirring. The solvent was filtered off using filter paper (Whatman No.1, Fitchburg, WI, USA) and the filtrate obtained was concentrated under reduced pressure on a rotary evaporator at $40{ }^{\circ} \mathrm{C}$ and finally freeze dried using a freeze-drying machine (LabConco, Kansas City, MO, USA). The dried seed extracts obtained from both water jug seeds (WJ) and basketball seeds (BB) were then stored at $4{ }^{\circ} \mathrm{C}$ for further use for various investigations. 


\subsubsection{Total phenol content (TPC) determination}

Total phenolic content was determined using Folin-Ciocalteu reagent following the method of Singleton and Rossi, (1965) and using gallic acid as a standard. An amount of $10 \mu \mathrm{l}$ of each WJ and BB dried seed extract solution $\left(1 \mathrm{mg} \mathrm{ml}^{-1}\right)$ was added in a test tube followed by the addition of $0.5 \mathrm{ml}$ of 1:10 Folin-Ciocalteu reagent. The mixture was incubated at room temperature for 5 minutes. Following incubation, $0.35 \mathrm{ml}$ of $115 \mathrm{mg} \mathrm{ml}^{-1}$ natrium carbonate $\left(\mathrm{Na}_{2} \mathrm{CO}_{3}\right)$ was added and mixed thoroughly. The mixture was then allowed to stand at room temperature for 2 hours. Absorbance reading taken spectrophotometrically at $765 \mathrm{~nm}$ and all determinations were done in triplicates. The total phenolic content of WJ and BB were expressed as milligrams of gallic acid equivalent to grams of dried seed extract.

\subsubsection{Total flavonoid content (TFC) determination}

Total flavonoid content of WJ and BB seed extracts were determined by aluminum chloride colorimetric method using quercetin as a standard (Chang et al., 2002). Briefly, $0.5 \mathrm{ml}$ of each seed extract solution $\left(1 \mathrm{mg} \mathrm{ml}^{-1}\right)$ was sampled in a test tube and mixed with $1.5 \mathrm{ml}$ ethanol $95 \%, 0.1 \mathrm{ml}$ aluminum chloride and $2.8 \mathrm{ml}$ distilled water. The mixtures were left to incubate for 30 minutes at room temperature followed by reading the absorbance at $415 \mathrm{~nm}$. The total flavonoid content of $\mathrm{WJ}$ and $\mathrm{BB}$ were expressed as milligrams of quercetin equivalent to grams of dried plant material.

\subsubsection{Ferric reducing antioxidant power (FRAP) de- termination}

Ferric reducing activity of the $\mathrm{WJ}$ and $\mathrm{BB}$ seed extracts was estimated using the method developed by Benzie and Strain (1996), while vitamin C (Vit. C) was taken as reference. The principle of the method depends on the chelating power of substances to ferric tripyridyltriazine complex. Briefly, the working FRAP reagent was freshly prepared by mixing $300 \mathrm{mmol} \mathrm{l}^{-1}$ acetate buffer, $10 \mathrm{mmol} \mathrm{l}^{-1}$ TPTZ (2, 4, 6-tripyridyls-triazine) in $40 \mathrm{mmol} \mathrm{l}^{-1}$ of HCL and $20 \mathrm{mmol} \mathrm{l}^{-1}$ of $\mathrm{FeCl}_{3} .6 \mathrm{H}_{2} \mathrm{O}$. The prepared mixture was then incubated at $35^{\circ} \mathrm{C}$ in water bath for five minutes and then a blank reading was taken spectrophotometrically at $593 \mathrm{~nm}$. A quantity of $10 \mu \mathrm{l}$ of each extract/reference was sampled separately and mixed with $290 \mu$ of the working FRAP reagent followed by vortexing and reading the absorb- ance immediately at $593 \mathrm{~nm}$ to get the record of zero minutes. Thereafter, the absorbance reading was taken every four minutes for a period of 2 hours. All the results were expressed as mmol ferric reducing activity of the extract per gram of dried weight based on three experiments.

\subsubsection{DPPH free radical scavenging activity deter- mination}

In the DPPH radical scavenging test, the scavenging of DPPH is followed by monitoring the decrease in absorbance at $515 \mathrm{~nm}$ that occurs due to reduction by the antioxidant or reaction with a radical species. DPPH is widely used to test for the ability of compounds to act as hydrogen donors or free radical scavengers and to evaluate antioxidant activity of foods (Kadhim et al., 2019). Scavenging activity of the WJ and BB dried seed extracts to the stable 2, 2 diphenyl-1-picryl dyhydrazyl (DPPH) free radical was determined according to the method of Gorinstein et al. (2005) with slight modification. Briefly, the dried seed extracts and the reference standard (ascorbic acid) were prepared $\left(1 \mathrm{mg} \mathrm{ml}^{-1}\right)$ as separate stock solutions and then serial dilution with 8 varying concentrations were prepared $(0.37,0.78,1.56$, $3.125,6.25,12.5,25,50 \mu \mathrm{l})$ from each stock solution. Five microliters of each sample was loaded in 96-well plate followed by the addition of $195 \mu$ l of DPPH reagent; the mixtures were then incubated in the dark at room temperature for 2 hours. At the end of the incubation period, the absorbance was measured spectrophotometrically at $515 \mathrm{~nm}$ with a Hitachi spectrophotometer (Hitachi, LTD.Tokyo, Japan), the DPPH percentage inhibition was calculated using the following formula:

$\mathrm{DPPH}(\%)=[($ Abs of blank-Abs of sample $) /$ Abs of blank] $\times 100$.

The results were expressed as $\mathrm{IC}_{50}$ value which is the extract concentration required to reduce $50 \%$ of the DPPH free radical.

\subsection{IN VIVO ACUTE TOXICITY STUDY OF WJ AND BB METHANOL EXTRACTS OF DRIED SEEDS}

\subsubsection{Experimental animals}

Sixty adult and healthy Sprague Dawley (SD) rats (6-8 weeks old) were obtained from the Animal House, Faculty of Medicine, University of Malaya, Kuala Lumpur (Ethic no.PM/30/05/2012/NSIAW (R). The body 
mass of SD rats was between $195-210 \mathrm{~g}$. The animals were fed standard rat pellets and tap water.

\subsubsection{Acute toxicity test}

The acute toxicity study was performed to determine the safe dosage of the dried seed extracts. Sixty $\mathrm{SD}$ rats (30 males and 30 females) were randomly and equally divided into 5 groups per sex. The groups were categorized as control (10\% Tween $\left.20,5 \mathrm{ml} \mathrm{kg}^{-1}\right)$, high dose WJ extract $5 \mathrm{~g} \mathrm{~kg}(\mathrm{HD}-\mathrm{WJ})$, low dose WJ extract $2 \mathrm{~g} \mathrm{~kg}^{-1}$ (LD-WJ), high dose BB extract $5 \mathrm{~g} \mathrm{~kg}^{-1}$ (HD-BB), and low dose BB extract $2 \mathrm{~g} \mathrm{~kg}^{-1}$ (LD-BB) (Co-operation and Development, 2002). To prepare the animals for dosing, they were allowed to fast for 14 hours without accessing food but with free access to water. All the rats were weighed recording the body mass on day 0 . After dosing, food was prevented for an additional four hours and the rats were observed for $30 \mathrm{~min}$ and 2, 4, 8, 24 and 48 hours, post dosing for the appearance of any clinical or toxicological signs such as respiration, salivation, diarrhoea, tremors, eyes and mucus membrane, skin and fur, sleep pattern and any signs associated with the nervous system. The presence of any morbidity, mortality or behavioural changes was recorded. At the end of the experimental period, the body mass of all the rats was recorded. On the 15th day, the animals were given over-dose of anaesthesia (xylazine with ketamine) then sacrificed to collect their blood for biochemistry study and kidneys and livers for histology study. Serum biochemical parameters were investigated at University of Malaya Medical Centre using a Hitachi Autoanalyzer, Japan, after optimizing the machine as previously performed ( $\mathrm{Al}$ Batran et al., 2013). Liver function parameters were assayed for total protein, albumin, globulin and conjugated bilirubin. In addition aspartate aminotransferase (AST), alanine aminotransferase (ALT) and gamma-glutamyl tansferase (GGT) were measured as markers of liver injury (Fujii 1997; Young et al., 2008).

\subsection{STATISTICAL ANALYSIS}

Statistical analysis of the data was carried out by using the statistical program for the social sciences (SPSS) version 16 while applying the ANOVA test for comparing means, followed by Post-Hoc Tukey test. All the data were expressed as mean \pm standard deviation (SD) of triplicates of the in vitro study and $\mathrm{n}=6$ for the in vivo study. The statistical value $p \leq 0.05$ was considered significant.

\section{RESULTS AND DISCUSSION}

\subsection{IN VITRO ANTIOXIDANT RESULTS}

\subsubsection{TPC and TFC of WJ and BB methanol extracts of dried seeds}

Antioxidants are the compounds that when added to food products, especially to lipids and lipid-containing foods, can increase the shelf life retarding the process of lipid peroxidation, which is one of the major reasons for deterioration of food products during processing and storage. Synthetic antioxidants, such as butylatedhydroxyanisole (BHA) and butylatedhydroxytolune (BHT), have restricted use in foods as they are suspected to be carcinogenic via their binding ability to DNA and cellu-

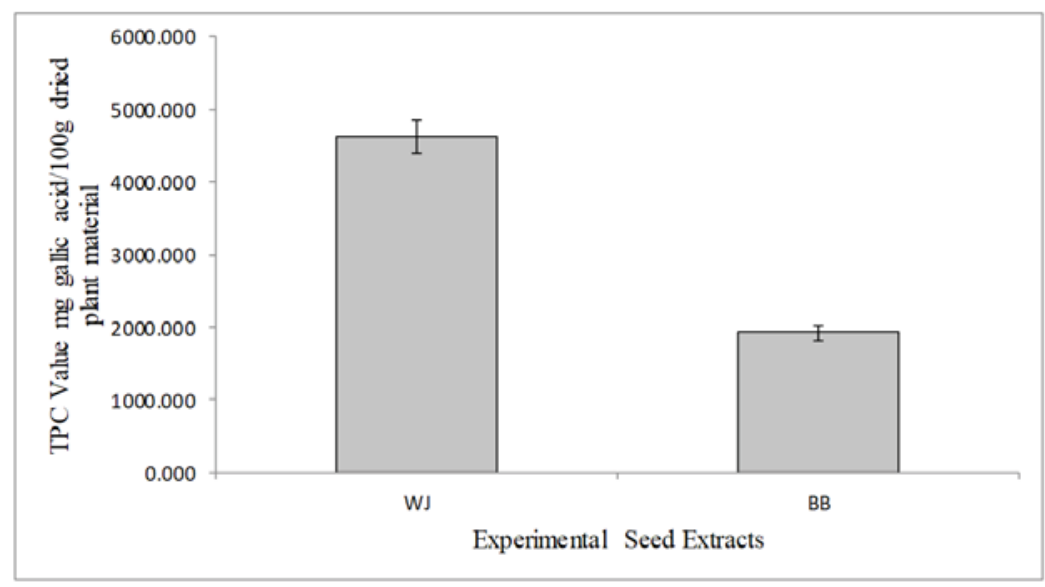

Figure 1: Total phenol content (TPC) of the methanol extracts of sweet gourd 'Water Jug' (WJ) and bitter gourd 'Basket Ball' (BB) dried seed extract 


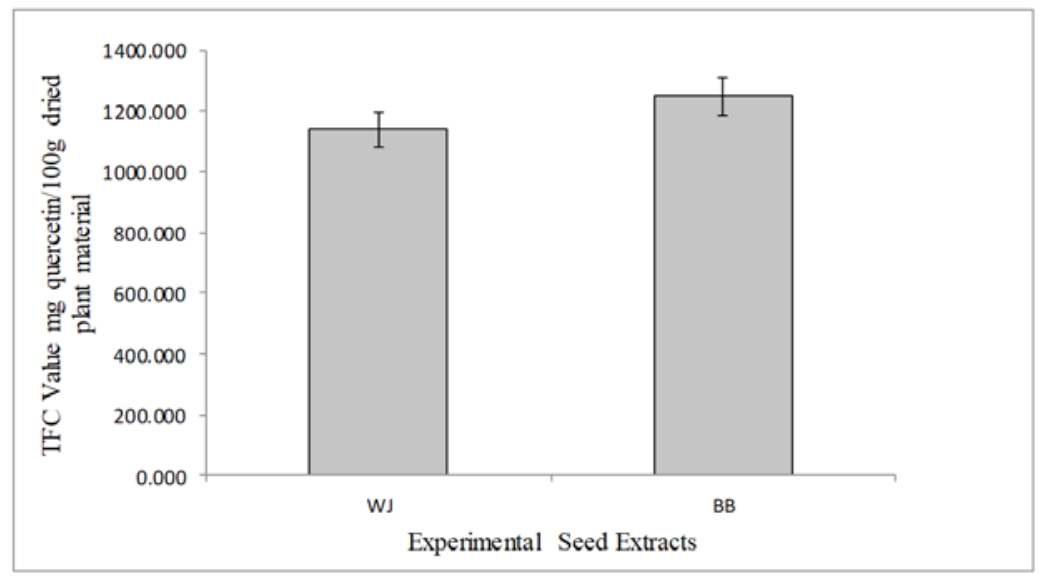

Figure 2: Total flavonoid content (TFC) of the methanol extracts of sweet gourd 'Water Jug' (WJ) and bitter gourd 'Basket Ball' (BB) dried seed extract

lar components (Dolatabadi and Kashanian, 2010; Mirza, Asema, and Kasim, 2017). Therefore, the exploitation of natural antioxidants, especially those of plant origin became necessary and attracted the attention of researchers in recent years (Moayedi et al., 2017). Aras et al. (2017) defined antioxidants as the substances that are capable of quenching or stabilizing free radicals.

In the present study, the seeds of dry fruits of two Lagenaria siceraria varieties, (sweet gourd Water Jug (WJ) and bitter gourd Basket Ball (BB) were ground, defatted and extracted in methanol and then tested for their total phenol and total flavonoid contents. The results of total phenol content (TPC) measured from the methanol extract of WJ and BB dried seeds are displayed in Fig.1. Results revealed that WJ seeds measured approximately two and half folds more than $\mathrm{BB}$ seeds indicating higher TPC of WJ seeds compared to $\mathrm{BB}$ seeds. The results of total flavonoid content (TFC) determined from the methanol extract of $\mathrm{WJ}$ and $\mathrm{BB}$ dried seeds are illustrated in Fig.2. Presented data recorded that the total flavonoid content of $\mathrm{BB}$ seeds was higher compared to that of WJ seeds.

\subsubsection{FRAP and DPPH results of $\mathrm{WJ}$ and $\mathrm{BB}$ methanol extracts of dried seed}

Free radicals, often called reactive oxygen species (ROS) and they are the core of any biochemical process representing a vital part in metabolism (Sangeetha and Venkatalakshmi, 2017). On the other hand, free radicals are highly generated in many pathological conditions and involved in the development and progress of common chronic degenerative diseases such as cardiovascular and neurodegenerative diseases, diabetes and cancer (Umeno et al., 2017). Disturbance in the balance between the formation of free radicals in the cells and their antioxidants load leads to oxidative stress that damages cellular components such as proteins, lipids and nucleic acids, and eventually leads to cell death (Shaker and Mnaa, 2017).

The FRAP values of $\mathrm{WJ}$ and $\mathrm{BB}$ seed extracts were displayed in Fig. 3 compared to vitamin $C$ standard. The scavenging abilities of $\mathrm{WJ}$ and $\mathrm{BB}$ seed extracts to the stable DPPH free radical is diagrammed in Fig. 4 in comparison with ascorbic acid standard (vitamin C). Results recorded that $\mathrm{IC}_{50}$ of both dried seed extracts were significantly higher than that of ascorbic acid indicating less DPPH scavenging activity compared to ascorbic acid. However, the WJ seed extract showed higher DPPH scavenging activity as indicated by the lower $\mathrm{IC}_{50}$ value compared to $\mathrm{BB}$ seed extract.

Studying the chemical composition of natural products plays a crucial role in screening their biological activities. Natural products having a sufficient antioxidant capacity contain mainly phenolic and flavonoid compounds which exhibit a broad range of biological activities such as anticancer, anti-inflammation, anti-aging and anti-atherosclerosis (Rahman et al., 2013). Antia et al. (2015) studied the antioxidant activity of short-hybrid variety of Lagenaria siceraria seeds reporting that the methanol seed extract of that variety acquires significant antioxidant activity and the seeds can be used as excellent natural antioxidant. Later, another study conducted on the seed oil of short-hybrid variety and revealed significant DPPH scavenging activity (Antia et al. 2016).

In the present study, the seeds of dry fruits of two $\mathrm{La}$ genaria siceraria varieties, (sweet gourd 'Water Jug' (WJ) and bitter gourd 'Basket Ball' (BB) were ground, defatted and extracted in methanol and then tested for their total phenol and total flavonoid contents, their reducing power to Fe (III) and their ability to scavenge the stable DPPH free radical. The methanol extract of both seeds exposed high 


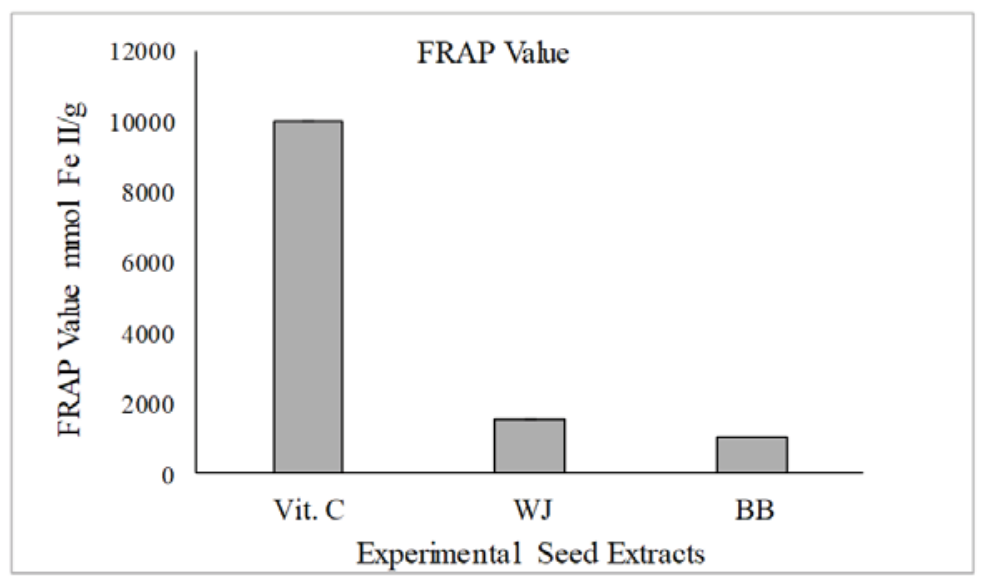

Figure 3: Ferric reducing antioxidant power (FRAP) of the methanol extracts of sweet gourd 'Water Jug' (WJ) and bitter gourd 'Basket Ball' (BB) dried seeds

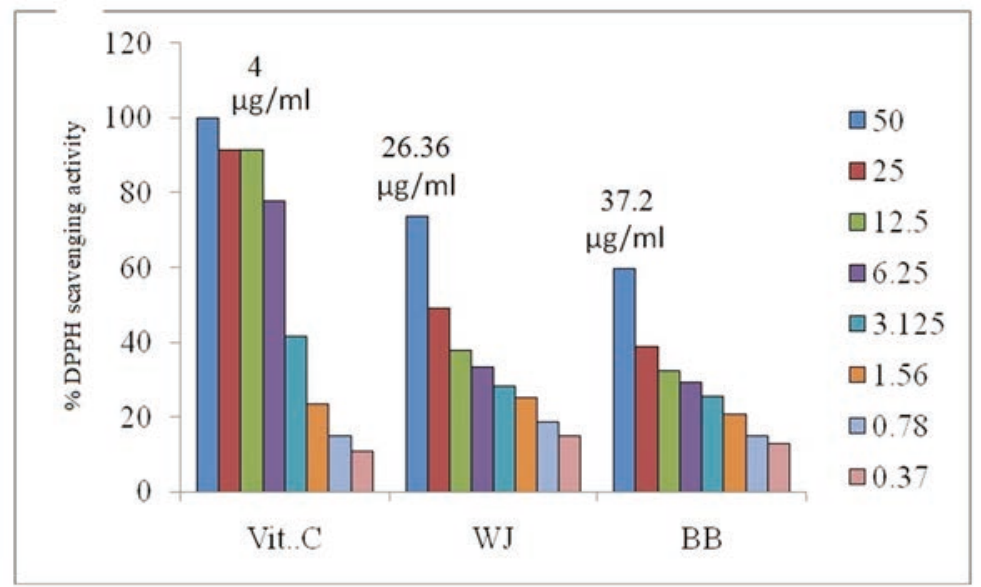

Figure 4: DPPH scavenging activities of the methanol extracts of sweet gourd 'Water Jug' (WJ) and bitter gourd 'Basket Ball' (BB) dried seeds compared to ascorbic acid standard (vitamin C). $\mathrm{IC}_{50}$ values are indicated on the bars.

antioxidant activity. Although WJ seeds acquired higher phenolic contents, FRAP and DPPH activity more than $\mathrm{BB}$ seeds extract, but $\mathrm{BB}$ seeds showed higher TFC compared to WJ seeds. Our study is consistent with a previous study on the remarkable antioxidant capacity of $L$. siceraria seeds (Satvir et al., 2012). Based on the results of DPPH of ascorbic acid, plant extracts WJ and BB, the $\mathrm{R}$-squared $\left(\mathrm{R}^{2}\right)$ values of the standard curve equations generated were $0.9516,0.9478$ and 0.9765 , respectively. All values were close to 1.0 indicating acceptable standard curves for all the tested samples ascorbic acid, WJ and BB (Salama et al., 2013). Recent studies on the antioxidant power of natural products manifested that they are very well recognized antioxidants, playing vital role in protecting biological cells and tissues from the detrimental effects of free radicals (Zeb and Mehmood, 2004). Therefore, they can be promising pharmaceutical com- pounds in preventing cancer and degenerative diseases as well (Olszowy, 2019).

\subsection{IN VIVO ACUTE TOXICITY RESULTS}

Acute toxicity studies in animals are usually necessary for any pharmaceutical substance intended for human use. The information obtained from these studies is useful in selecting doses for repeat-dose studies, providing preliminary identification of target organs of toxicity, and, occasionally, revealing delayed toxicity. Acute toxicity studies may also aid in the selection of starting doses for Phase 1 human studies, and provide information relevant to acute overdosing in humans (CDER and FDA, 1996). Past studies on acute toxicity of petroleum ether, ethanol and chloroform extracts of $L$. siceraria fruits in 
rats recommended safe dose up to $2 \mathrm{~g} \mathrm{~kg}^{-1}$ (Deshpande et al., 2008). Additionally, previous study on the acute toxicity and sub-chronic toxicity of the methanol extract of L. siceraria aerial parts showed that it is quite safe and can be used in the treatment of chronic diseases like diabetes (Saha et al., 2011). In the present study, the methanol extracts of $\mathrm{WJ}$ and $\mathrm{BB}$ dried seeds of $L$. siceraria revealed safe dose up to $5 \mathrm{~g} \mathrm{~kg}^{-1}$.

The findings from the acute toxicity study did not indicate any morbidity or mortality from treating male and female SD rats with the methanol extracts of WJ and BB dried seeds at doses $2 \mathrm{~g} \mathrm{~kg}^{-1}$ and $5 \mathrm{~g} \mathrm{~kg}^{-1}$ throughout the 14 days study period. Physical observation of the treated rats throughout the study didn't show any changes on skin, fur, eyes, mucus membrane, behaviour pattern, tremors, salivation or sleep. In addition no diarrhea or coma observed on any of the treated rats from both sexes.

Table 1: Effects of WJ and BB dried seed extracts on the body mass of the rats

\begin{tabular}{llc}
\hline Groups & Body mass (g) day 0 & Body mass (g) day 14 \\
\hline $10 \%$ Tween 20, male & $202.50 \pm 4.4$ & $208.16 \pm 3.7$ \\
$10 \%$ Tween 20, female & $194.16 \pm 8.5$ & $196.83 \pm 8.9$ \\
HD-WJ, male & $205.16 \pm 4.5$ & $207.66 \pm 5.3$ \\
HD-WJ, female & $195.33 \pm 7.5$ & $198.00 \pm 7.4$ \\
LD-WJ, male & $205.16 \pm 4.8$ & $207.66 \pm 5.1$ \\
LD-WJ, female & $194.16 \pm 8.4$ & $196.00 \pm 7.0$ \\
HD-BB, male & $205.83 \pm 3.6$ & $207.33 \pm 3.6$ \\
HD-BB, female & $194.50 \pm 7.9$ & $196.00 \pm 7.5$ \\
LD-BB, male & $205.83 \pm 9.3$ & $208.00 \pm 8.1$ \\
LD-BB, female & $193.16 \pm 10.5$ & $196.00 \pm 10.0$
\end{tabular}

Values expressed as mean $\pm \mathrm{SD}$, the significant value was set at $p \leq 0.05$.

Table 2: Effects of WJ and BB dried seed extracts on renal function parameters

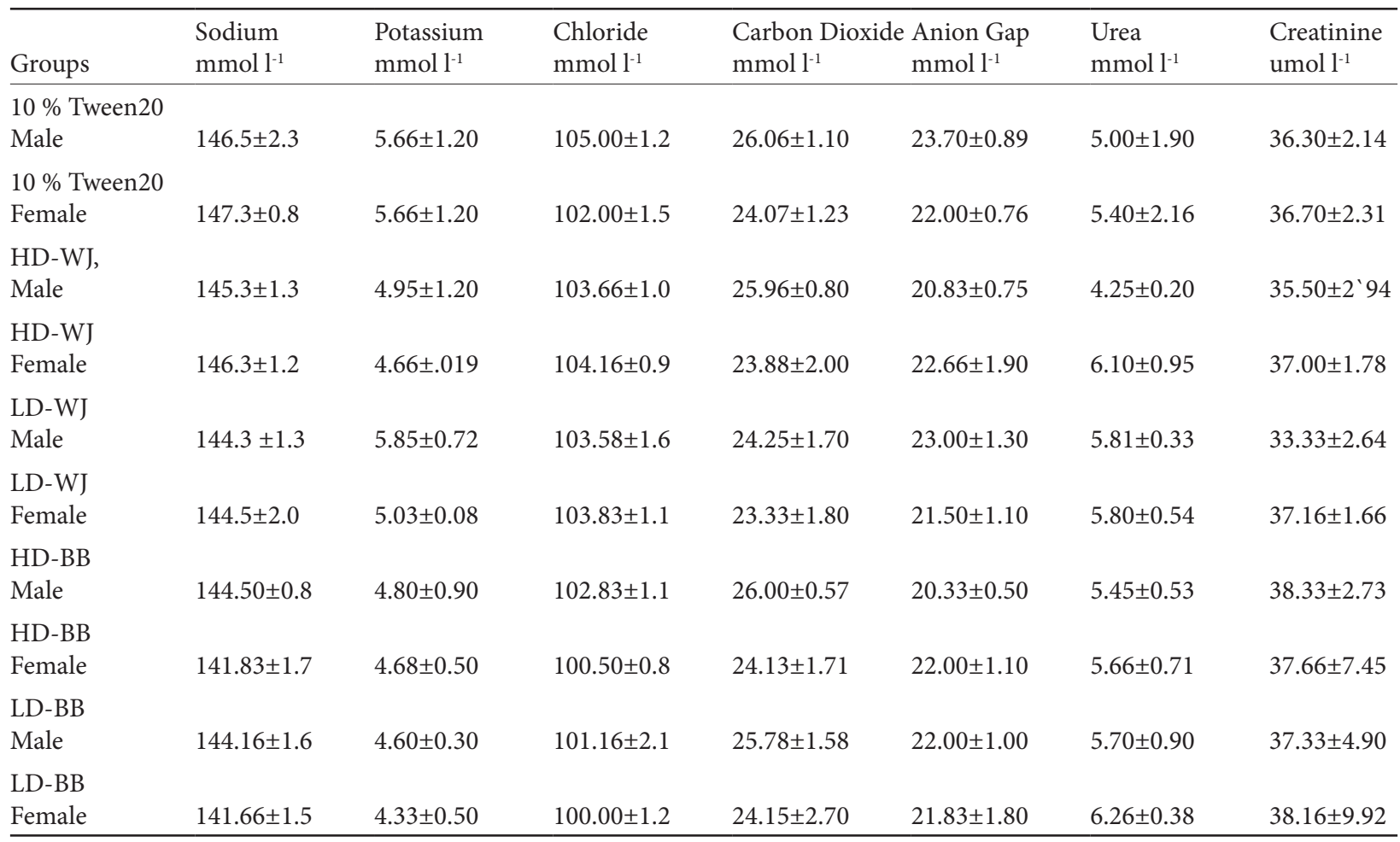

Values expressed as mean $\pm \mathrm{SD}$, the significant value was set at $p \leq 0.05$. 


\subsubsection{Effect of WJ and BB dried seed extracts on body mass of rats}

The body mass measurements of the treated and control rats on day 0 and day 14 are shown in Table 1. Data showed reasonable increase in the body mass of the treated and control rats. In addition, the body mass of the treated rats were insignificantly different as compared to control.

\subsubsection{Effect of WJ and BB dried seed extracts on renal function test}

Renal function parameters of both WJ-treated and BB-treated rats are presented in Table 2. From the results, the concentration of all measured parameters (sodium, potassium, chloride, carbon dioxide, anion gap, urea, and creatinine) in the animals treated with the low dose $\left(2 \mathrm{~g} \mathrm{~kg}^{-1}\right)$ and high dose $\left(5 \mathrm{~g} \mathrm{~kg}^{-1}\right)$ of both seed extracts were insignificant compared to control rats. The concentration of all measured parameters (sodium, potassium, chloride, carbon dioxide, anion gap, urea, and creatinine) is lying within the normal range, however there was slight increase in the concentration of anion gap and decrease in creatinine level, but they were alike in both control and treated groups indicating safe treatment. This showed that the seed extract at different levels tested did not produce considerable change in the levels of the different parameters studied.

\subsubsection{Effect of WJ and BB seed extracts on liver function test}

Table 3 reorded the effects of the low dose (2 $\left.\mathrm{g} \mathrm{kg}^{-1}\right)$ and high dose $\left(5 \mathrm{~g} \mathrm{~kg}^{-1}\right)$ of both WJ and $\mathrm{BB}$ methanol extracts of dried seeds on liver function parameters. No significant changes were observed in the values of the parameters studied [(total protein, albumin, globulin, conjugated bilirubin, aspartate aminotransferase (AST) and gama glutamyl transferase (GGT),] in comparison with the control animals and the values obtained were within the normal biological and laboratory limit. On the other hand, the total bilirubin recorded slight decrease than normal ranges and showed significant difference in the low and high doses of BB-treated rats of both sexes compared to control. Additionally, alanine aminotransferase (ALT) revealed slight elevation than normal ranges.

Table 3: Effects of WJ and BB dried seed extracts on liver function parameters

\begin{tabular}{|c|c|c|c|c|c|c|c|}
\hline & Total protein & Albumin & Globulin & Total bilirubin & ALT & AST & GGT \\
\hline Groups & $\mathrm{g} \mathrm{l}^{-1}$ & $\mathrm{~g} \mathrm{l}^{-1}$ & $\mathrm{~g} \mathrm{l}^{-1}$ & $\mathrm{mmol} \mathrm{l}^{-1}$ & $\mathrm{IU} \mathrm{l}^{-1}$ & $\mathrm{IU} \mathrm{l}^{-1}$ & IU 1 \\
\hline $\begin{array}{l}10 \% \text { Tween } \\
20 \text { Male }\end{array}$ & $69.33 \pm 2.9$ & $40.33 \pm 0.80$ & $28.67 \pm 1.20$ & $3.50 \pm 1.00$ & $46.83 \pm 2.00$ & $47.12 \pm 9.1$ & $<3$ \\
\hline $\begin{array}{l}10 \% \text { Tween } \\
20 \text { Female }\end{array}$ & $72.66 \pm 4.3$ & $37.83 \pm 0.70$ & $34.83 \pm 1.90$ & $3.50 \pm 0.54$ & $45.16 \pm 2.30$ & $46.66 \pm 8.3$ & $<3$ \\
\hline $\begin{array}{l}\text { HD-WJ } \\
\text { Male }\end{array}$ & $68.16 \pm 3.3$ & $36.83 \pm 0.40$ & $31.33 \pm 0.51$ & $3.00 \pm 0.00$ & $49.16 \pm 300$ & $44.92 \pm 5.6$ & $<3$ \\
\hline $\begin{array}{l}\text { HD-WJ } \\
\text { Female }\end{array}$ & $70.60 \pm 40$ & $35.00 \pm 0.80$ & $35.60 \pm 2.00$ & $2.83 \pm 0,40$ & $41.50 \pm 2.10$ & $48.33 \pm 60$ & $<3$ \\
\hline $\begin{array}{l}\text { LD-WJ } \\
\text { Male }\end{array}$ & $68.83 \pm 0.88$ & $39.00 \pm 0.63$ & $29.83 \pm 2.10$ & $2.83 \pm 0.46$ & $48.66 \pm 2.70$ & $49.45 \pm 7.2$ & $<3$ \\
\hline $\begin{array}{l}\text { LD-WJ } \\
\text { Female }\end{array}$ & $66.66 \pm 1.4$ & $43.16 \pm 1.30$ & $23.50 \pm 1.80$ & $3.33 \pm 1.80$ & $46.00 \pm 1.90$ & $46.66 \pm 11$ & $<3$ \\
\hline $\begin{array}{l}\text { HD-BB } \\
\text { Male }\end{array}$ & $63.66 \pm 2.2$ & $37.33 \pm 0.80$ & $26.33 \pm 5.30$ & $2.33 \pm 0.50^{*}$ & $41.83 \pm 8.70$ & $49.66 \pm 10$ & $<3$ \\
\hline $\begin{array}{l}\text { HD-BB } \\
\text { Female }\end{array}$ & $69.16 \pm 2.1$ & $35.00 \pm 0.90$ & $34.16 \pm 7.10$ & $1.50 \pm 1.70^{*}$ & $38.33 \pm 6.20$ & $45.00 \pm 13$ & $<3$ \\
\hline $\begin{array}{l}\text { LD-BB } \\
\text { Male }\end{array}$ & $62.50 \pm 1.9$ & $36.00 \pm 0.60$ & $26.50 \pm 5.50$ & $1.83 \pm 1.90^{*}$ & $43.83 \pm 5.10$ & $42.83 \pm 16$ & $<3$ \\
\hline $\begin{array}{l}\text { LD-BB } \\
\text { Female }\end{array}$ & $68.83 \pm 3.9$ & $38.50 \pm 2.20$ & $30.33 \pm 4.10$ & $1.33 \pm 2.50^{*}$ & $40.16 \pm 3.40$ & $47.50 \pm 9.5$ & 4 \\
\hline
\end{tabular}

Values expressed as mean $\pm \mathrm{SD}$, the significant value was set at $p \leq 0.05 .{ }^{*} p<0.05$ compared to normal control 


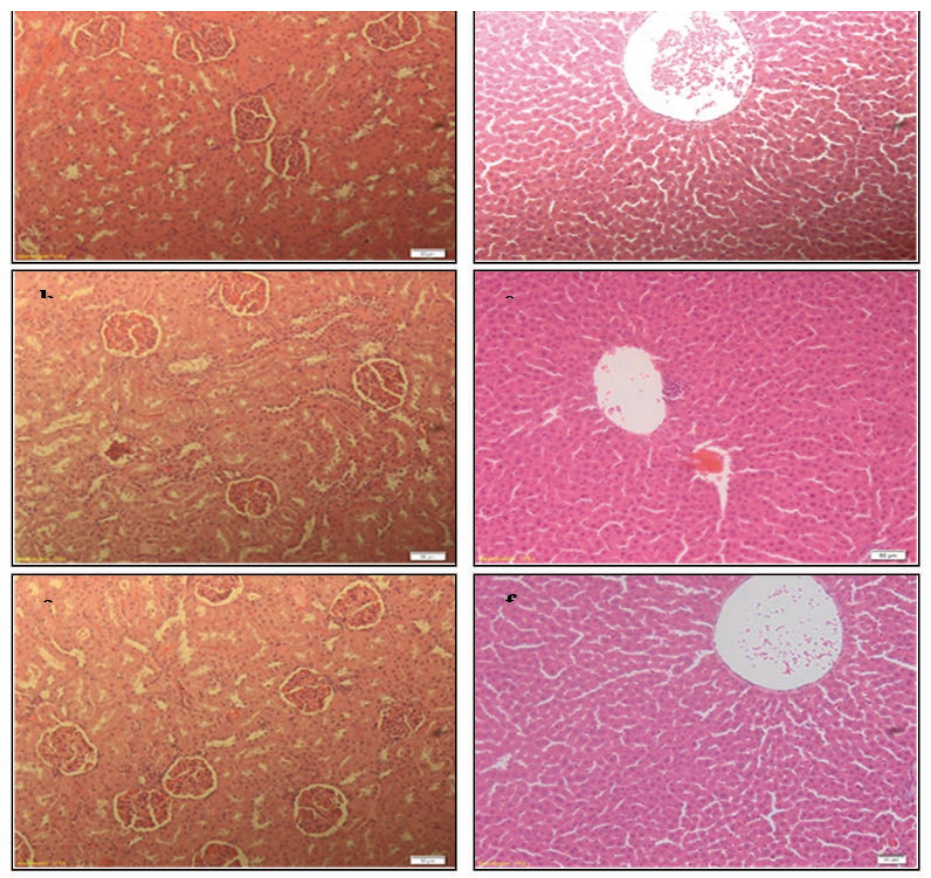

Figure 5: Histological sections (20 x magnifications) of kidneys and livers from the acute toxicity test on the methanol extract of WJ and BB dried seeds. (a \& d) Vehicle kidney and liver respectively treated with $5 \mathrm{ml} \mathrm{kg}^{-1}$ (10\% Tween 20). (b \& e) Kidney and liver respectively treated with $\mathrm{WJ}$ seed extracts $\left(5 \mathrm{~g} \mathrm{~kg}^{-1}\right)$. (c \& f) Kidney and liver respectively treated with BB seed extract.

\subsubsection{Effect of WJ and BB dried seed extracts on the histopathology of liver and kidney of rats}

The qualitative data from the histological sections of kidneys and livers collected from the control and rats treated with $\mathrm{WJ}$ and $\mathrm{BB}$ seed extracts at the highest dose tested $\left(5 \mathrm{~g} \mathrm{~kg}^{-1}\right)$ are illustrated on Fig. 5. No significant difference was observed between the architecture of livers or kidneys collected from the WJ-treated and BBtreated animals compared to control group.

\section{CONCLUSION}

In conclusion, the current study showed that the methanol extracts of both $\mathrm{WJ}$ and $\mathrm{BB}$ dried seeds of $L$. siceraria possesses high antioxidant power. The WJ seeds variety reported higher TPC, FRAP and DPPH values than $\mathrm{BB}$ variety, while the TFC results of $\mathrm{BB}$ seeds variety recorded higher value than that of WJ. The acute toxicity test of the methanol extract of both seed varieties reported safe dose up to $5 \mathrm{~g} \mathrm{~kg}^{-1}$ in both sexes of rats.

\section{ACKNOWLEDGEMENTS}

The authors would like to express their great thankful to the staff of immunology lab, Department of Mo- lecular Medicine, Faculty of Medicine and Lipid lab, Department of Chemistry, Faculty of Science, University Malaya for their un limited support and cooperation during the practical period of the study.

\section{REFERENCES}

Achigan-Dako, E. G., Fagbemissi, R., Avohou, H. T., Vodouhe, R. S., Coulibaly, O., Ahanchede, A. (2008). Importance and practices of Egusi crops (Citrullus lanatus (Thunb.) Matsum. Nakai, Cucumeropsis mannii Naudin and Lagenaria siceraria (Molina) Standl. 'Aklamkpa') in sociolinguistic areas in Benin. Biotechnologie, Agronomie, Société et Environnement, 12(4), 393-403.

Al Batran, R., Al-Bayaty, F., Al-Obaidi, M. M. J., Abdulla, M. A. (2013). Acute toxicity and the effect of andrographolide on porphyromonas gingivalis-induced hyperlipidemia in rats. BioMed research international, Volume 2013, Article ID 594012, 7 pages http://dx.doi.org/10.1155/2013/594012

Antia, B. S., Essien, E. E., Udoh, B. I. (2015). Antioxidant capacity of phenolic from seed extracts of Lagenaria siceraria (short-hybrid bottle gourd). European Journal of Medicinal Plants, 9(1), 1-9. https://doi.org/10.9734/EJMP/2015/18242

Antia, B. S., Essien, E. E., Peter N. S. (2016). Antioxidant capacity and total polyphenolics from seed oils of various cultivars of Lagenaria siceraria. Indo American Journal of Pharmaceitic Science, 3(5).

Aras, A., Silinsin, M., Bingol, M. N., Bursal, E. (2017). Identification of Bioactive Polyphenolic Compounds and As- 
sessment of Antioxidant Activity of Origanum acutidens. International Letters of Natural Sciences, 66, 1-8. https://doi. org/10.18052/www.scipress.com/ILNS.66.1

Benzie, I. F. and Strain, J. J. (1996). The ferric reducing ability of plasma (FRAP) as a measure of "antioxidant power": the FRAP assay. Analytical biochemistry, 239(1), 70-76. https:// doi.org/10.1006/abio.1996.0292

CDER, and FDA. (1996). Guidance for industry: single dose acute toxicity testing for pharmaceuticals (Final).

Chang, C.-C., Yang, M.-H., Wen, H.-M., Chern, J.-C. (2002). Estimation of total flavonoid content in propolis by two complementary colorimetric methods. Journal of food and drug analysis, 10(3), 178-182. https://doi.org/10.38212/22246614.2748

Co-operation, O. f. E., \& Development. (2002). Test No. 423: Acute Oral Toxicity-Acute Toxic Class Method: OECD Publishing.

Deshpande, J., Choudhari, A., Mishra, M., Meghre, V., Wadodkar, S., Dorle, A. (2008). Beneficial effects of Lagenaria siceraria (Mol.) Standley fruit epicarp in animal models. In dian Journal of Experimental Biology, 46, 234-242.

Dolatabadi, J. E. N., \& Kashanian, S. (2010). A review on DNA interaction with synthetic phenolic food additives. Food Research International, 43(5), 1223-1230. https://doi. org/10.1016/j.foodres.2010.03.026

Elhadi, I. M., Koko, W. S., Dahab, M. M., El Imam, Y. M., \& El Mageed, M. A. E. A. (2013). Antigiardial activity of some Cucurbita species and Lagenaria siceraria. Journal of Forest Products and Industries, 2(4), 43-47.

Erickson, D. L., Smith, B. D., Clarke, A. C., Sandweiss, D. H., \& Tuross, N. (2005). An Asian origin for a 10,000-yearold domesticated plant in the Americas. Proceedings of the National Academy of Sciences of the United States of America, 102(51), 18315-18320. https://doi.org/10.1073/ pnas.0509279102

Fader, M., Gerten, D., Krause, M., Lucht, W., Cramer, W. (2013). Spatial decoupling of agricultural production and consumption: quantifying dependences of countries on food imports due to domestic land and water constraints. Environmental Research Letters, 8(1), https://doi. org/10.1088/1748-9326/8/1/014046

Firestone, D. (2009). Official methods and recommended practices of the AOCS: AOCS.

Fujii, T. (1997). Toxicological correlation between changes in blood biochemical parameters and liver histopathological findings. Journal of Toxicological Sciences, 22, 161-83. https://doi.org/10.2131/jts.22.3_161

Ghule, B., Ghante, M., Upaganlawar, A., Yeole, P. (2006). Analgesic and anti-inflammatory activities of Lagenaria siceraria Stand. fruit juice extract in rats and mice. Pharmacognosy magazine, 2(8), 232-238.

Gill, N., Singh, S., Arora, R., \& Bali, M. (2012). Evaluation of ethanolic seed extract of Lagenaria siceraria for their therapeutic potential. Journal of Medical Sciences, 12(3), 78-84. https://doi.org/10.3923/jms.2012.78.84

Gorinstein, S., Drzewiecki, J., Leontowicz, H., Leontowicz, M., Najman, K., Jastrzebski, Z., Katrich, E. (2005). Comparison of the bioactive compounds and antioxidant potentials of fresh and cooked Polish, Ukrainian, and Israeli garlic. Jour- nal of agricultural and food chemistry, 53(7), 2726-2732. https://doi.org/10.1021/jf0404593

Kadhim, N. J., Al-Rekaby, L. S., Abdul Redha, A., Chappell, J. (2019). Chemical composition and antioxidant capacity of eggplant parts during vegetative and flowering stage. To cite: Journal of Physics: Conf. Series 1294 (2019) 092013 IOP Publishing, https://doi.org/10.1088/17426596/1294/9/092013.

Kumar, D., Sharma, C., Singh, B., Singh, D. (2015). Pharmacognostical, phytochemical and pharmacological profile of natural remedy Lagenaria siceraria (Mol.) Standly: A Review. British Journal of Pharmaceutical Research, 7(5), 340352. https://doi.org/10.9734/BJPR/2015/17641

Mayakrishnan, V., Veluswamy, S., Sundaram, K. S., Kannappan, P., \& Abdullah, N. (2013). Free radical scavenging potential of Lagenaria siceraria (Molina) Standl fruits extract. Asian Pacific journal of tropical medicine, 6(1), 20-26. https://doi. org/10.1016/S1995-7645(12)60195-3

Mirza, S. K., Asema, U., Kasim, S. S. (2017). To study the harmful effects of food preservatives on human health. Journal of Medicinal Chemistry and Drug Discovery, 2(2), 610-616.

Moayedi, A., Mora, L., Aristoy, M.-C., Hashemi, M., Safari, M., Toldrá, F. (2017). ACE inhibitory and antioxidant activities of peptide fragments obtained from tomato processing byproducts fermented using Bacillus subtilis: Effect of amino acid composition and peptides molecular mass distribution. Applied biochemistry and biotechnology, 181(1), 48-64. https://doi.org/10.1007/s12010-016-2198-1

Olszowy, M. (2019). What is responsible for antioxidant properties of polyphenolic compounds from plants?. Plant Physiology and Biochemistry, 144, 135-143. https://doi. org/10.1016/j.plaphy.2019.09.039

Rahman, H., Manjula, K., Anoosha, T., Nagaveni, K., Eswaraiah, C., Bardalai, D. (2013). In-vitro antioxidant activity of Citrullus lanatus seed extracts. Asian Journal of Pharmaceutical and Clinical Research, 6(3), 152-157.

Saha, P., Mazumder, U., Haldar, P., Islam, A., \& Kumar, R. S. (2011). Evaluation of acute and subchronic toxicity of $L a$ genaria siceraria aerial parts. International Journal of Pharmaceutical Sciences and Research, 2(6), 1507-1512.

Salama, S. M., AlRashdi, A. S., Abdulla, M. A., Hassandarvish, P., \& Bilgen, M. (2013). Protective activity of Panduratin A against thioacetamide-induced oxidative damage: demonstration with in vitro experiments using WRL-68 liver cell line. BMC complementary and alternative medicine, 13(1), 1-9. https://doi.org/10.1186/1472-6882-13-279

Sangeetha, M. and Venkatalakshmi, P. (2017). In Vitro antioxidant activity of the aqueous extract of Andrographis paniculata and Carica papaya leaves. World Journal of Pharmacy and Pharmaceutical Sciences, 6(5), 1631-1643. https://doi. org/10.20959/wjpps201705-9229

Satvir, S., Gill, N., Arora, R. (2012). Study the antioxidant activity of Lagenaria siceraria seeds. International Journal of Natural Product Sciences, 1, 224.

Shah, B., Seth, A., \& Desai, R. (2010). Phytopharmacological profile of Lagenaria siceraria: a review. Asian Journal of Plant Sciences, 9(3), 152-157. https://doi.org/10.3923/ ajps.2010.152.157

Shaker, E. and Mnaa, S. (2017). Protective effect of some lo- 
cal plants against oxidative stress caused by hydrogen peroxide. Journal of Environmental and Toxicological Studies, 1(1), https://doi.org/10.16966/2576-6430.104

Singh, M., Mohd, F., Ayaz, A., Ankur, S., \& Jyoti, Y. (2012). Protective effect of Lagenaria siceraria against doxorubicin induced cardiotoxicity in wistar rats. International Journal of Drug Development and Research, 4(2), 298-295.

Singleton, V. L. and Rossi, J. A. (1965). Colorimetry of total phenolics with phosphomolybdic-phosphotungstic acid reagents. American journal of Enology and Viticulture, 16(3), 144-158.

Sivannarayana, T., Hussain, S. S., \& Jithendra, K. P. (2013). Pharmacological and pharmaceutical applications of $L a-$ genaria siceraria. International Journal of Pharmacy and Pharmaceutical Sciences, 1(4), 288-292.

Sood, A., Kaur, P., \& Gupta, R. (2012). Phytochemical screening and antimicrobial assay of various seeds extract of cucurbitaceae family. International Journal of Applied Biology and Pharmaceutical Technology, 3(3), 401-409.

Srivastava, V., Rao, C., \& Panday, A. (2011). ntiulcer activity of methanolic fruit extract of Lagenaria siceraria (Mol.) Standly. International Journal of Pharmaceutical Research and Development, 3(7), 187-192.
Thakkar, J. H. (2013). Evaluation of invitro antimutagenic potential of Lagenaria siceraria using Ame's test. American Journal of Cancer Biology, 1(2), 57-61.

Umeno, A., Biju, V., Yoshida, Y. (2017). In vivo ROS production and use of oxidative stress-derived biomarkers to detect the onset of diseases such as Alzheimer's disease, Parkinson's disease, and diabetes. Free Radical Research, 51(4), 413-427. https://doi.org/10.1080/10715762.2017.1315114

Upaganlawar, A. and Balaraman, R. (2011). Cardioprotective effects of Lagenaria siceraria fruit juice on isoproterenolinduced myocardial infarction in wistar rats: a biochemical and histoarchitecture study. Journal of Young Pharmacists, 3(4), 297-303. https://doi.org/10.4103/0975-1483.90241

Young, T. H ., Tang, H. S., Chao, Y. C., Lee, H. S., Hsiong, C. H., Pao, L. H., Hu, O. Y. P. (2008). Quantitative rat liver function test by galactose single point method. Laboratory Animals, 42(4), 495-504. https://doi.org/10.1258/ la.2007.06040e

Zeb, A., \& Mehmood, S. (2004). Carotenoids contents from various sources and their potential health applications. Pakistan Journal of Nutrition, 3(3), 199-204. https://doi. org/10.3923/pjn.2004.199.204 